\title{
野球バットの打撃性能評価と打者のスイング能力に基づいた選択
}

\author{
香川 博之*1 , 高橋 昌也 ${ }^{* 2}$, 佐藤 一孝*3, 溝口 正人*4 \\ 米山 猛茥，北川 雄二郎*5，那須 英彰*5，武田 憲明*5
}

\section{Evaluation on hitting performance of baseball bats and their selection according to swing ability of a player}

\author{
Hiroyuki KAGAWA ${ }^{* 1}$, Masaya TAKAHASHI ${ }^{* 2}$, Kazutaka SATO ${ }^{* 3}$, Masato MIZOGUCHI*4, \\ Takeshi YONEYAMA ${ }^{* 1}$, Yujiro KITAGAWA ${ }^{* 5}$, Hideaki NASU ${ }^{* 5}$ and Noriaki TAKEDA ${ }^{* 5}$ \\ ${ }^{*} 1,{ }^{*} 5$ Department of Mechanical Engineering, Kanazawa University \\ Kakuma-machi, Kanazawa-shi, Ishikawa 920-1192, Japan \\ ${ }^{*}$ Anjo Works, UACJ Extrusion Nagoya Corporation \\ 1 Kitayamazaki-cho, Anjo-shi, Aichi 446-8691, Japan \\ ${ }^{* 3}$ Ena Works, UACJ Metal components Corporation \\ 18-1 Nagashima-cho Kusumi, Ena-shi, Gifu 509-7206, Japan \\ ${ }^{* 4}$ Human Life Technology Research Institute, Toyama Industrial Technology Center \\ 35-1 Iwatakeshin, Nanto-shi, Toyama 939-1503, Japan
}

Received 13 October 2016; Accepted: 16 January 2017

\begin{abstract}
In this study, a new technique has been proposed to quantitatively evaluate the hitting performance of baseball bats without affecting their initial pitching velocity; this technique is based on an earlier evaluation system developed to measure the same. The experiments conducted in this study were used to calculate two parameters, namely "hitting efficiency index" and "hitting velocity index," to demonstrate the relation between the pitching and hitting velocity of the baseball bat and evaluate the bat's hitting performance. To evaluate the hitting performance, this method required fewer experiments than the previously developed method. Furthermore, on the basis of the calculations of these two parameters, the swinging ability of a baseball bat was found to be corresponded to the bat's moment of inertia. Using the parameters proposed in this method along with the pitching velocity, a player can estimate the hitting velocity of the bat when used in a match. Therefore, this method, when adopted, can help players choose baseball bats depending on their individual playing abilities.
\end{abstract}

Key words : Baseball, Bat, Ball, Batting, Estimating method, Hitting performance, Moment of inertia, Velocity, Selecting method

\section{1. 緒言}

様々の種類の野球バットが市販されている．購入する際にどのバット選ぶのかなどを考える上で，打撃性能を 定量的に判断するための情報は，まだ十分に提供されていないのが現状である.この情報不足はバットを開発・ 製造する者にとっても同様のことである.これまでに野球バットやボールの特性，打撃性能の評価法に関する研 究などが多方面で行われ，多くの有用な成果が報告されている．例えば高木（高木, 1983）や Adair（Adair, 1996） は，著書の中でバットのスイートスポットの意味について考察し打球の飛翔軌道のシミュレーションなどにより 打撃全般の解説を行っている，鳴尾ら（鳴尾他，1992）や西川ら（西川他, 1994）は，バット開発に関連し反発係数 測定方法の提案や測定結果などを示している．田中ら（田中他，1992）は強度評価に関連し金属バット内に生じる打撃

No.16-00097 [DOI: 10.1299/transjsme.16-00097], J-STAGE Advance Publication date: 25 January, 2017

${ }^{* 1}$ 正員，金沢大学理工研究域（广920-1192 石川県金沢市角間町）

*2 (株) UACJ 押出加工名古屋安城製作所（广446-8691 愛知県安城市北山崎町 1)

*3 (株) UACJ 金属加工恵那工場（广509-7206 岐阜県恵那市長島町久須見 18-1）

*4 正員, 富山県工業技術センター生活工学研究所（一939-1503 富山県南砺市岩武新 35-1）

*5 元金沢大学

E-mail of corresponding author: kagawa@t.kanazawa-u.ac.jp 
Kagawa, Takahashi, Sato, Mizoguchi, Yoneyama, Kitagawa, Nasu and Takeda, Transactions of the JSME (in Japanese), Vol.83, No.846 (2017)

時のひずみ波の測定を行っている. Cross（Cross, 1999）やNathan（Nathan, 2000）は打撃による衝撃解析を行い, スイートスポットについて考察し, Jaramillo ら（Jaramillo et al., 2003）はその実測を試みている. Nathan ら (Nathan et al., 2004）はさらにトランポリン効果についても検討している. Smith（Smith, 2001）は, バットの打撃性能に ついて検討をし，Smith ら（Smith and Ison, 2006）はソフトボールについても調べている. 背戸ら（背戸，山下， 1992），秦ら（秦他, 2004）, 渡邊ら（渡邊, 岩原, 2013）は, バットの振動モード解析を行い打撃性能との関係に ついて考察している. 神田ら（神田他, 2004）は軟式ボールのモデル化に成功し, 尾田ら（尾田他, 2004）や仁村ら（仁 村他，2011）は硬式ボールのモデル化を試みており，実験ではなく解析による新たなバット開発の試み（例えば，北出 他，(2014））などもある. その他，Nicholls ら（Nicholls et al., 2005）によるピッチャーの怪我に関連し打球速度に ついての検討，Drane ら（Drane et al., 2006）によるバットの耐久性，Russell（Russell, 2006）のバット振動の減衰 に関する検討などもある。

打撃性能評価は，バットにボールを衝突させて反発特性を測定するのが一般的である．しかし，小林ら（小林 他, 2014）が示しているように, 衝突速度すなわち投球速度やバットのスイング速度の影響を受ける. 実際の試合 中におけるバットの打撃性能について検討するためには，衝突速度を何通りにも変え，たくさんの評価実験を行 ってデータ収集しなければならないという問題がある，また，ある衝突速度における様々なバットの打撃性能を 比較したい場合でも，同一投球速度で評価試験を行うことが難しく，しかもボールの個体差や劣化によってボー ル自体の特性も変化する，すなわち実験的に評価条件自体を一致させることが難しく, 評価条件がばらつくため にその評価值もさらに大きくばらつくことになる.

選手個人の能力に合わせた野球バットの開発を目指して，著者らはこれまで作成してきた野球バットの様々な 衝突速度における打撃性能特性について把握寸る必要があった．また，選手が使用する野球バットを選択する場 合の指針についてバットの打撃性能を考慮したものは著者らの知る範囲ではなかった，そこで，打撃性能評価シ ステムを開発し，その概要とバットの反発特性評価結果を分類したものを報告（那須他，2005）している．前報

（香川他，2011）では，そのうちの評価システムの概要と打撃時のバット支持方法の影響についてまとめた．本 報では，バットの打撃性能特性についてまとめなおし，具体的な評価方法や評価值のもつ意味について詳細に説 明する．また，投球速度の影響を受けない新しいパラメータを導入した評価法を提案する．さらに，選手のスイ ング能力を調べ，その選手に適したバットを選択する簡便方法についても提案する．なお，本報は主に実験や評 価を実施した 2006 年頃までの情報や実験結果に基づいて整理したものである.

\section{2. 打撃性能評価の方法}

\section{$2 \cdot 1$ バットの反発係数}

本研究では，前報（香川他，2011）で開発した回転自由支持の野球バット反発係数測定装置を利用してバット の打撃性能評価を行う，紙面の都合上，ここでは装置の概略図等は省略するので，詳細は前報を参照されたい． 回転自由支持し静止したバットにボールを衝突させる，すなわち打撃するとき，投球速度 $v_{0}$, 打球速度 $v_{1}$, 打撃 後のバットの回転速度 $\omega_{1}$ とすると，ボールとバットの反発係数（以後，バットの反発係数と呼ぶ） $e_{b a t}$ は

$$
e_{b a t}=\frac{v_{1}-R \omega_{1}}{v_{0}}
$$

により求められる．なお，打撃位置は，回転中心からバット先端側に距離 $R$ だけ移動した点とする．また，本研 究では回転中心をグリップ端から $152[\mathrm{~mm}]$ の位置とする.ここで, バットの回転中心回りの慣性モーメントを $I$, ボールの質量を $m$ とすると，打撃前後の角運動量保存則より

$$
R m v_{0}=-R m v_{1}+I \omega_{1}
$$

の関係が導かれる.

したがって，式(1)から打撃後のバットの回転速度 $\omega_{1}$ を 


$$
e_{b a t}=\frac{m R^{2}}{I}+\left(1+\frac{m R^{2}}{I}\right) \frac{v_{1}}{v_{0}}
$$

のように消去できる．このような打撃実験を行うと，実際には $v_{0}, v_{1}, \omega_{1}$ の測定值が大きくばらつき， $e_{b a t}$ を評 価するには多くの実験を行って平均值を取るなどの処理が必要になる. また，複数のバットの反発係数を比較す るとき，投球速度を同一にする必要があるが，条件を完全に合わせるのは非常に難しい．

例として, あるバット $\left(I=0.177\left[\mathrm{~kg} \cdot \mathrm{m}^{2}\right], R=533[\mathrm{~mm}]\right)$ において投球速度 $v_{0}$ を種々変えて, 打球速度 $v_{1}$ との関 係について図 1 中に○で示す．なお，前報の測定装置では最高投球速度が約 $41.7[\mathrm{~m} / \mathrm{s}] （ 150[\mathrm{~km} / \mathrm{h}] ）$ の 2 ローター 回転式ピッチングマシンを使用していたが，広い投球速度範囲について確かめるため, 本研究では最高投球速度 が約 $69.4[\mathrm{~m} / \mathrm{s}](250[\mathrm{~km} / \mathrm{h}])$ のガス銃式ピッチングマシンも使用している. 参考までに 2 ローター回転式ピッチン グマシンによる実験結果を示すと図 1 中の のようになり，これらのデータから外挿して高速領域について推定 した結果が，○で示したガス銃式の結果とほぼ一致していることも確認できた。すなわち，高価なガス銃式を使 用せず，安価な 2 ローター式ピッチングマシンでもそれなりに評価可能であることを示している．また， 3 種類 の投球速度を設定したにもかかわらず, 投球速度は各設定值 $(70[\mathrm{~km} / \mathrm{h}], 120[\mathrm{~km} / \mathrm{h}], 160[\mathrm{~km} / \mathrm{h}])$ の近傍でばらつき, その範囲は投球速度が大きいほど顕著になり, 前章で述べた投球速度を一定にした実験実施の難しさを示してい る. 他のバットについて調べたところ同様の分布傾向を示し, 本研究の範囲では打球速度 $V_{1}$ は

$$
v_{1}=a v_{0}^{b}
$$

で近似できることがわかった。ここで，aおよび $\mathrm{b}$ はバットにより決まる定数パラメータであり，式には特に物 理的な意味はない. なお，本研究では， $v_{0}, v_{1}$ の単位を一般的に選手が使っているものに合わせ，どちらも $[\mathrm{km} / \mathrm{h}]$ にした.

したがって, 図 1 のように投球速度を変えて評価実験を行うことにより, 式(4)の 2 つの定数パラメータ $a, b$ を求めれば，任意の投球速度 $v_{0}$ におけるバットの反発係数 $e_{b a t}$ は

$$
e_{b a t}=\frac{m R^{2}}{I}+\left(1+\frac{m R^{2}}{I}\right)\left(a v_{0}^{b-1}\right)
$$

により評価できることになる. なお，図 1 では $a=0.786, b=0.777$ となっていた.

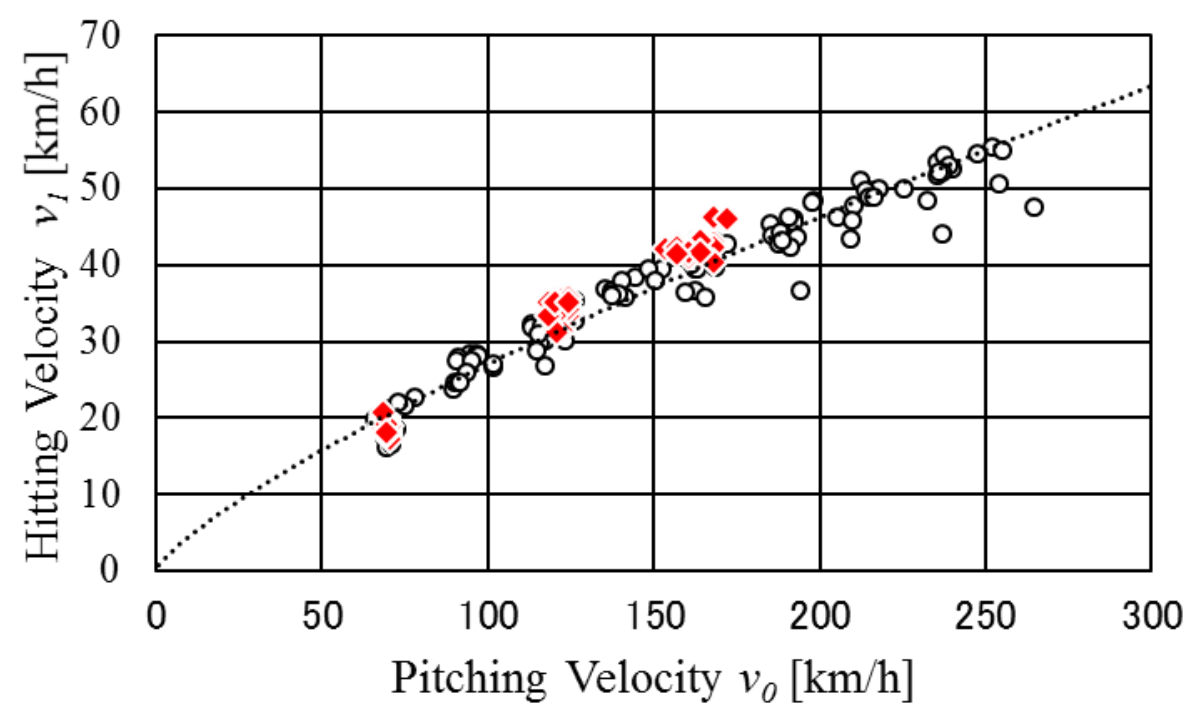

Fig.1 Example of relation between pitching and hitting velocity during evaluation test 


\section{$2 \cdot 2$ バットの打撃効率係数}

評価実験より得られるバットの反発係数（ボールとバットの反発係数） $e_{b a t}$ は, ボール自身の反発係数（ボール 之剛体壁の反発係数） $e_{\text {ball }}$ の影響を受けて変化する. ボールの影響を受けないバットの反発特性を表すため, 本 研究では次式で示すような $h_{e}$ を打撃効率係数と定義した.

$$
h_{e}=\frac{e_{b a t}}{e_{\text {ball }}}
$$

これは，仮想的に $e_{\text {ball }}$ が 1 のボールをバットで打撃したときのバットの反発係数を表しており，ASTM の規格 （ASTM F1881，1998）ではBPF（Bat Performance Factor）と定義されているものである．h h が大きいほど反発 効率がよく, 打撃後のエネルギー損失が小さいことを表している.ただし，後述するように，バットの慣性モー メントの影響も受けるため, $h_{e}$ だけが大きくても打撃後の打球速度が大きくなるとは限らないことに注意が必要 である.

\section{$2 \cdot 3$ ボールの反発係数}

打撃効率係数 $h_{e}$ の評価には, ボール自体の反発係数を把握する必要がある. 野球ボールの反発係数は, 壁面に 固定された剛体板すなわち剛体壁にボールを衝突させて, 衝突前後のボールの速度比から評価（ASTM F1887, 2002a）されている. 本研究では，ボールの反発係数評価を目的にした特別な打撃具を新たに作成し，バット反発 係数測定装置を利用して同様の評価をすることを考えた. 具体的には, ステンレス製の直径 $25[\mathrm{~mm}]$, 長さ $900[\mathrm{~mm}]$ の剛体棒に縦 100[mm], 横 $120[\mathrm{~mm}]$, 板厚 20[mm]の長方形板を固定した回転剛板（図 2）を作成し, 野球バット の代わりに使用した．なお，図 2 は打撃面の裏側から見たものである.

バットと同様に回転剛板のグリップ端から $152[\mathrm{~mm}]$ の位置を回転中心とし，長方形板の中心にボールを衝突さ せた，なお，本研究では打撃位置が打撃中心（撃心）になるように長方形板の固定位置を調整したところ, 打撃 位置と回転中心の距離 $R$ は $530[\mathrm{~mm}]$, 回転中心回りの回転剛板の慣性モーメント $I_{P}$ は, $0.850\left[\mathrm{~kg} \cdot \mathrm{m}^{2}\right]$ となった. また，ボールの質量 $m$ は $0.150[\mathrm{~kg}]$ であった.

評価実験を模式的に示寸と図 3 のようになる. (a)図は剛体壁にボールを衝突させる場合について示したもので あり, ボールの投球速度および反射速度すなわち打球速度をそれぞれ $v_{0 \mathrm{w}}$ おび $v_{\mathrm{lw}}$ とすると, 反発係数 $\boldsymbol{e}_{\text {ball }}$ は

$$
e_{\text {ball }}=\frac{v_{1 w}}{v_{0 w}}
$$

で表される.この衝突によりボールが失う運動エネルギーUは

$$
U=\frac{1}{2} m v_{0 w}^{2}\left(1-e_{\text {ball }}^{2}\right)
$$

で表される.

同様に, (b)図は回転剛板にボールを衝突させる場合について示したものであり, ボールの投球速度を $v_{0}$, 打球 速度を $v_{1}$ とし, 反発係数を $e_{\text {ball }}$ と寸れば，ボールが失う運動エネルギーUは

$$
U=\frac{1}{2} m v_{0}{ }^{2}\left(1-e_{\text {ball }}^{2}\right) \frac{I_{P}}{I_{P}+m R^{2}}
$$

で表される.

どちらの方法でも同じ条件でボールの反発係数を評価するためには，Uと $e_{\text {ball }}$ がそれぞれ一致すべきであるこ とから，それらを式(8)と式(9)から消去することで次式の関係を導出することができる.

$$
v_{0}=\sqrt{1+\frac{m R^{2}}{I_{P}}} v_{0 w}
$$


すなわち，投球速度 $v_{0 \mathrm{w}}$ で剛体壁にボールを衝突させる場合に対応した評価実験を，回転剛板にボールを衝突 させて行うためには，式(10)で換算した投球速度 $v_{0}$ を用いてバットの場合と同様にして回転剛板の反発係数評価 を行えばよいことになる．ここで，バットの代わりに回転剛板を用いれば，式(5)の $e_{\text {bat }}$ は $e_{\text {ball }}$ とみなせる. 実際 には, 本研究の場合には $m$ が小さく, $I_{P}$ が大きいため, 式(10)より誤差 $3 \%$ 未満で $v_{0 \mathrm{w}}$ と $v_{0}$ はほぼ等しいと考えて よい.

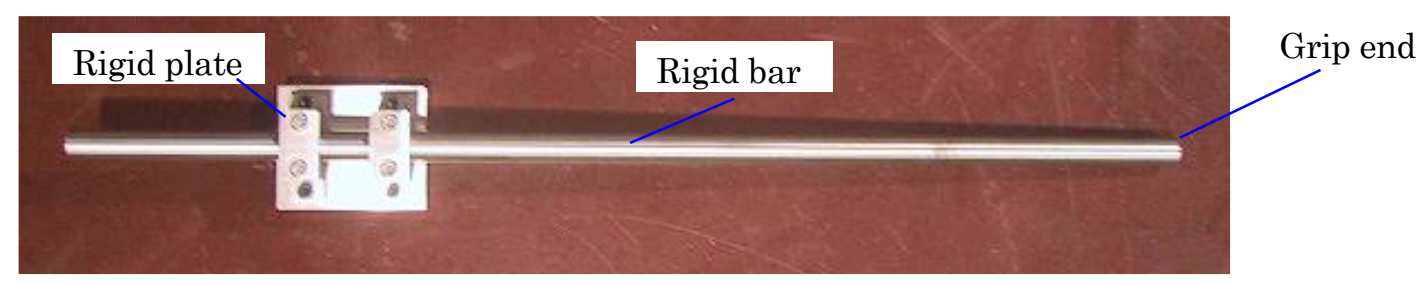

Fig.2 Rotational rigid plate



(a) Rigid wall

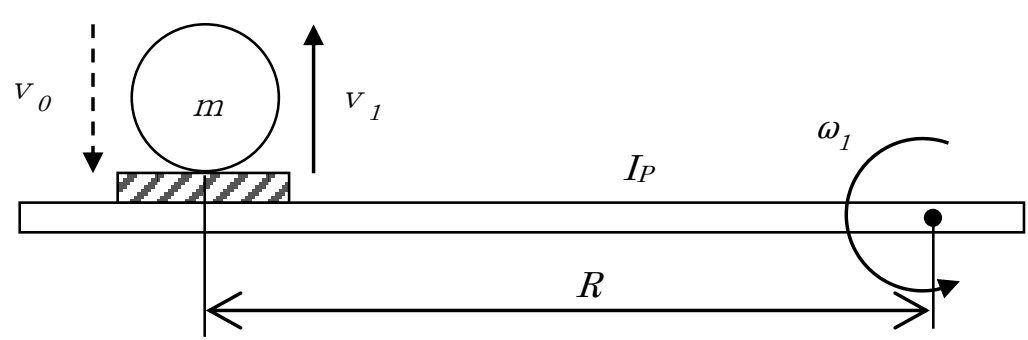

(b) Rotational rigid plate

Fig.3 Schematic chart to evaluate coefficient of restitution of ball

以上から, 本研究で作成した回転剛板をバットの代わりに使用して,バットの反発係数と同様の評価を行えば, 任意の投球速度におけるボールの反発係数 $e_{\text {ball }}$ を評価できることになる.

\section{$2 \cdot 4$ バットの打球速度係数}

先にも述べたが，同じ投球速度の条件でも，打撃効率係数 $h_{e}$ が大きいバットほど打球速度が大きくなるとは限 らない，そこで，本研究では評価実験により得られる投球速度 $v_{0}$ と打球速度 $v_{l}$ の比を打球速度係数 $h_{v}$

$$
h_{v}=\frac{v_{1}}{v_{0}}
$$

と定義した．同じ投球速度の場合，この $h_{V}$ が大きいバットほど打球速度が大きいことになる.

打撃前後の角運動量保存則の式(2)と式(1)，式(6)，式(11)より $h_{v}$ は

$$
h_{v}=\frac{\frac{I}{m R^{2}} h_{e} e_{\text {ball }}-1}{\frac{I}{m R^{2}}+1}
$$

のように整理できる. バットの打撃性能評価は，同一ボールで行うことが理想であるが，それは現実的には難し い. ここでは，打撃効率係数 $h_{e}$ が既知の場合に打球速度係数 $h_{v}$ を評価することを想定している．評価機関すなわ ち使用ボールの違いによる差を出さないために基準となるボールの反発係数 $e_{\text {ball }}$ を使った評価值に換算できるよ うに, 式中のパラメータに $e_{\text {ball }}$ を残した表現にしている.

式(12)を変形し，式(6)を代入すると 


$$
e_{b a t}=\frac{m R^{2}}{I}+\left(1+\frac{m R^{2}}{I}\right) h_{v}=B B C O R
$$

が得られる.これは式(2) と同じものであり, バットの反発係数 $e_{b a t}$, すなわち米国で使用されているバットの 打撃性能を表す指標のひとつである BBCOR (Bat-Ball Coefficient of Restitution) を $h_{v}$ で表現したものである. 式(12) より, 打球速度係数 $h_{v}$ は, バットの慣性モーメント $I$ やバットの打撃効率係数 $h_{e}$ の関数になり, $I$ が等しい場合 には $h_{e}$ が大きければ $h_{v}$ も大きくなることがわかる．しかし，Iが小さければ $h_{e}$ の影響が小さくなることに注意が 必要である.ここで，Iに以下のように現実的にはありえない極端な值を仮定すると，

$$
\begin{array}{ll}
I=0 \text { の場合 }: & h_{v}=-1 \\
I \rightarrow \infty \text { の場合 }: & h_{v} \rightarrow h_{e} e_{b a l l}=e_{b a t}=B B C O R
\end{array}
$$

となり， $h_{e}$ が大きいバットほど打球が大きくなるとは限らないことが確認できる.このことは，いくら打撃効率 係数 $h_{e}$ が大きく反発特性がよくても, 慣性モーメントIが小さければ打球は前方に飛ばない. すなわち, ゴム風 船のようなバットで打撃を行えば，打撃時のボール変形すなわちエネルギー損失が小さくなり反発係数は大きく なるかもしれないが，打球を打ち返すことが難しくなることを表している.

打球速度係数 $h_{v}$ は，見方を変えると式(4)と式(11)から

$$
h_{v}=a v_{0}{ }^{b-1}
$$

と表すことができる. すなわち, バットごとに打撃評価試験より求まる定数 $a$ および $\mathrm{b}$ は, 打球速度係数 $h_{v}$ の投 球速度に対する影響度および敏感度を表すようなパラメータになっていることがわかる.

米国で使用されているバットの打撃性能を表寸指標のひとつに BESR（Bat Exit Speed Ratio）（ASTM F2219， 2002b）があるが， $h_{v}$ とは次式のような関係になる.

$$
B E S R=h_{v}+0.5=a v_{0}^{b-1}+0.5
$$

\section{$2 \cdot 5$ 打者のスイング能力}

選手に適したバットを選択するには, 打者のスイング能力について個別に把握寸る必要がある. スイング 動作に関して多くの有用な研究 (例えば (前田他, 2000), (伊藤他, 2001), (小池他, 2006), (城所他, 2013) など）が報告されている. 打撃時のバットは, 選手のスイング動作によって並進運動と回転運動が 3 次元的 に組み合わされた複雑な運動となる。バットの打撃評価については, 打撃直前のバット打撃点の速度がわか ればよいことから, 本研究では簡便評価のためにも, スイング動作などについては考慮せず単に打撃直前の 打撃点の速度 (スイング速度)だけを測定することにした．打者は慣性モーメントが大きいバットを使うほ どスイング速度が小さくなる傾向にあり，その度合いが選手により異なる，そこで，本研究では素振りによ って, バットの慣性モーメントとスイング速度の関係を求めて, それを打者のスイング能力として評価寸る ことにした。

スイング速度の測定には，図 4 に示寸ように市販のバッティング用ティースタンドを用いた。これに練習用ス ポンジボールを乗せ，練習用マスコットバットで打撃した．打撃点の近傍に光センサーを 2 個取付けてある. な お，図では右打者と左打者に対応寸るために合計 4 個が取付けられている，スイング時にバットが順番にそのセ ンシングビームを遮蔽するようになっており，その 2 点間の距離（60[mm]）と通過時間から打撃直前のスイング 速度を測定した，マスコットバットの慣性モーメントは，おもり取付け位置を変えることで設定した．なお，バ ットには打撃目標位置の印をつけて, 同じ位置で打撃できるようにした。 また，グリップエンドから $152[\mathrm{~mm}]$ の 位置に印をつけ，打者は右手と左手の間にその印がくるようにバットを握った。 


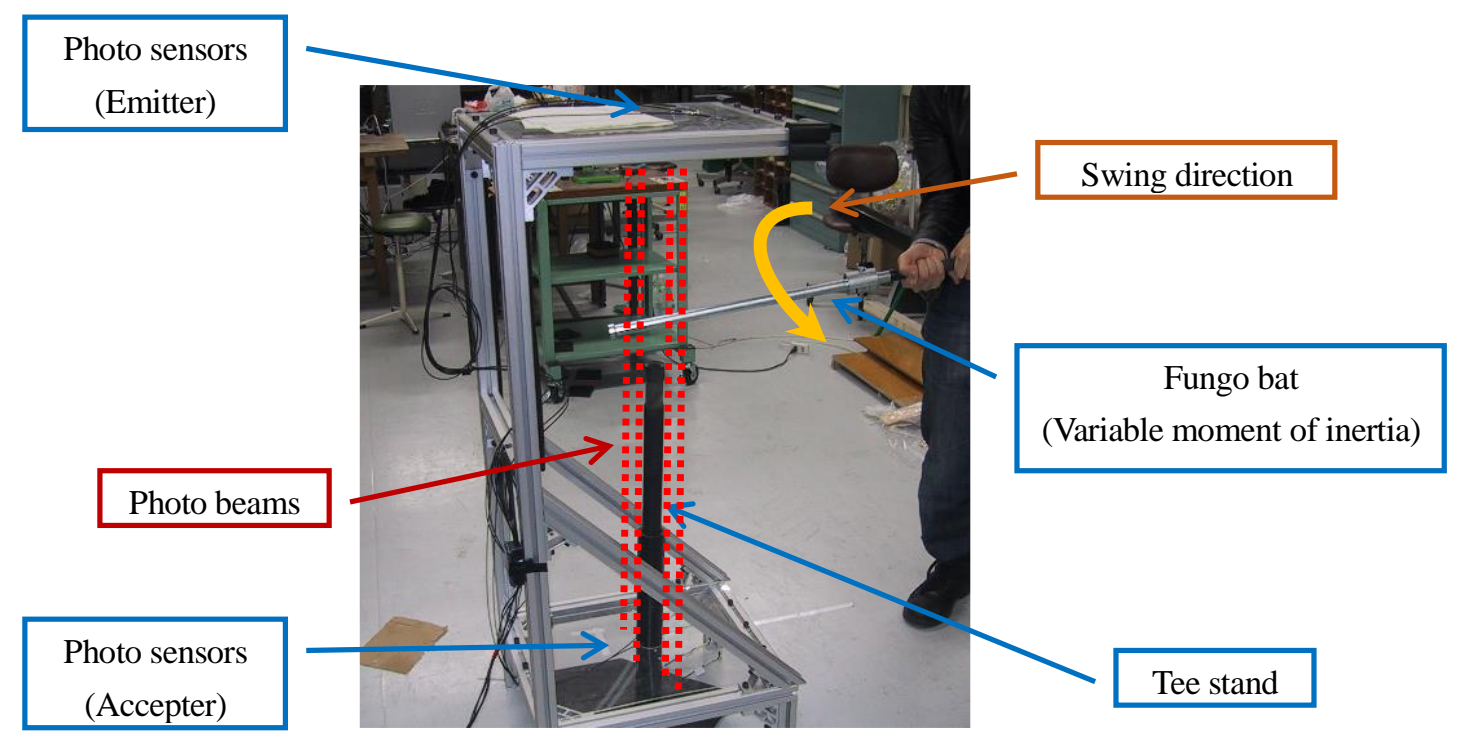

Fig.4 Measuring device for swing velocity of player

例として，慣性モーメント $I\left[\mathrm{~kg} \mathrm{~m}^{2}\right]$ とスイング速度 $V_{B}[\mathrm{~km} / \mathrm{h}]$ の関係を，ある打者について調べたところ図 5 に ○で示すようになった．他の打者についても同様に調べたところ，值は違うものの本研究の範囲ではほぼ同様の 減少傾向を示寸ことがわかった，そこで，本研究では打者のスイング能力を次式で表すことにした.

$$
V_{B}=A \ln (I)+B
$$

$V_{B}$ を $I$ の平方根に反比例するというモデル化を行えば，物理的意味のある実験式を得ることも可能であるが， $V_{B}$ によりスイング形態が大きく変化する打者もいることから, 本研究では式(18)を使用することにする. この式 には特に物理的な意味はないが，近似の程度から市販の野球バットを使用する範囲では十分に実用的な実験式と

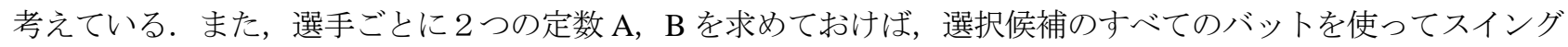
速度を測定しなくても，式(18)より任意慣性モーメントをもつバットにおけるスイング速度を推定できることに なり便利である，試しにある実際のバットで素振りをした結果を図に・でプロットしたが，図中に点線で示寸式 (18)の推定值によくあっていることがわかる. なお, 図 5 では $\mathrm{A}=-28.84, \mathrm{~B}=30.15$ となっていた.



Fig.5 Example of swing velocity of a player with a fungo bat 


\section{3. 打撃性能評価の結果例}

\section{$3 \cdot 1$ バットの打撃性能評価}

例として，投球速度 $v_{0}$ を $27.8[\mathrm{~m} / \mathrm{s}] （ 100[\mathrm{~km} / \mathrm{h}] ）$ に設定して，15 種類の野球バットの打撃性能評価を行った結 果を図 6 に示寸. どのバットについても打撃位置 $R$ を撃心の位置とした. 横軸は野球ボールの質量 $m$ と打撃位置 $R$ により無次元化したバットの慣性モーメント $I /\left(m R^{2}\right)$ で, 縦軸は打球速度係数 $h_{v}$ である. したがって, 図で左側 に位置するほどスイングしやすく，逆に右側に位置するほどスイングしにくいバットであることを示している. また，図で上側に位置するほど打球がよく飛ぶバットであることを示している.

図には式(13)にバットの反発係数 $e_{b a t}$ を与えることで得られる関係曲線を破線で示した. なお，基準ボールの反 発係数で無次元化すれば， $e_{b a t}$ を打撃効率係数 $h_{e}$ に換算して考えることもできる. この図は, 各バットの評価点 がごの曲線に近いかで， $e_{b a t}$ あるいは $h_{e}$ の值を知ることもでき，選手がバットの大まかな特性を簡単に把握して 比較するのに役立つものと考えている．したがって，図で左上側に位置するほど打撃効率がよく，逆に右下側に 位置するほど打撃効率がよくないバットであることを示している.

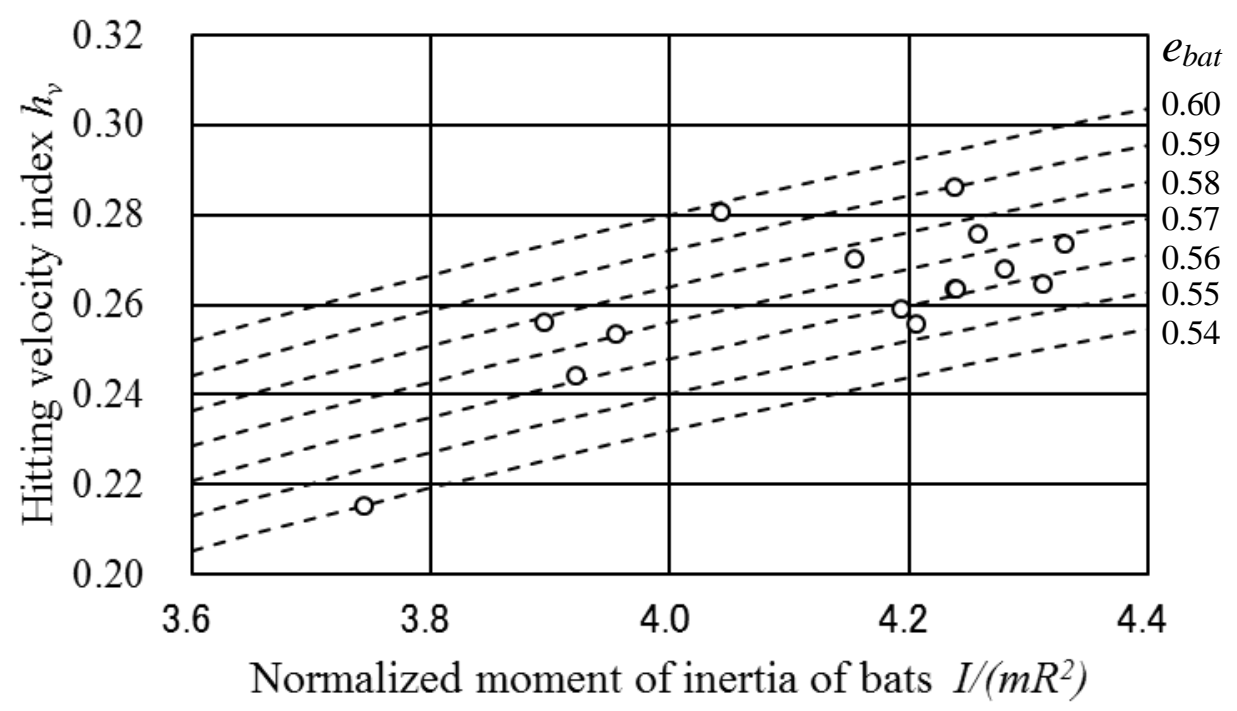

Fig. 6 Hitting velocity index $h_{v}$ for each bat at pitting velocity $100[\mathrm{~km} / \mathrm{h}]$

\section{$3 \cdot 2$ 選手に適したバット選択}

選手がさまざまな打撃性能をもつバットを使ったときの打球速度 $v_{l}$ にいて，打者のスイング能力を考慮して 推定を試みる.これまでの議論では，投球速度 $v_{0}$ で打撃直前までバットが静止している打撃性能試験を想定して いた．ボールに対して選手がスイング速度 $V_{B}$ で打撃することは，投球速度 $\left(v_{0}+V_{B}\right)$ の打撃試験を行うことと相 対的に同じ現象になる. 前節までの関係式を適用するためには, 実験系全体が相対速度 $V_{B}$ で移動していることを 仮定すればよい，すなわち，投球速度を $\left(v_{0}+V_{B}\right)$ に，打球速度を $\left(v_{1}-V_{B}\right)$ に置き換えて考えることと等価にな る。したがって，スイング速度 $V_{B}$ を考慮すると式(11)と式(16)は，

$$
\begin{aligned}
& h_{v}=\frac{v_{1}-V_{B}}{v_{0}+V_{B}} \\
& h_{v}=a\left(v_{0}+V_{B}\right)^{b-1}
\end{aligned}
$$

とすることができる. これらと式(18)から，打球速度 $v_{1}$ は

$$
v_{1}=a\left\{v_{0}+(A \ln (I)+B)\right\}^{b}+(A \ln (I)+B)
$$

のように表すことができる.なお, 米国で使用されているバットの打撃性能を表す指標のひとつに BBS (Batted-Ball Speed）（ASTM F2219，2002）があるが，この $v_{1}$ が打者のスイング能力を考慮した BBS ということになる. 
Kagawa, Takahashi, Sato, Mizoguchi, Yoneyama, Kitagawa, Nasu and Takeda,

Transactions of the JSME (in Japanese), Vol.83, No.846 (2017)

ある選手（特性值：A，B）が，あるバット（特性值： $\mathrm{a} ， \mathrm{~b} ， I$ ）を使って投球速度 $v_{0}$ のボールを打撃する場 合について，打球速度 $v_{1}$ を式(21)により推定できることになる. 例えば，図 5 の選手が図 6 に示したバットを使 って投球速度 $100[\mathrm{~km} / \mathrm{h}]$ のボールを打撃する場合, 打球速度は図 7 に示すように推定される. ここでは打撃をバッ トの撃心で行うものとした.また, 実験データのばらつきにより推定に使用寸る各特性值が確率変数となるため, $v_{1}$ の推定值も確率変数になり, 統計学的な有意差を調べる必要があるが, ここではそこまで踏み込んでいない.

この図より，ある選手がどのバットを使えばボールがよく飛ばせるかを定量的に把握できる．なお，同じバッ トでも，選手が変わればスイング能力が変わるため，この值は変化する．また，投球速度が変わってもバットの 打撃性能が変化することに注意が必要である.

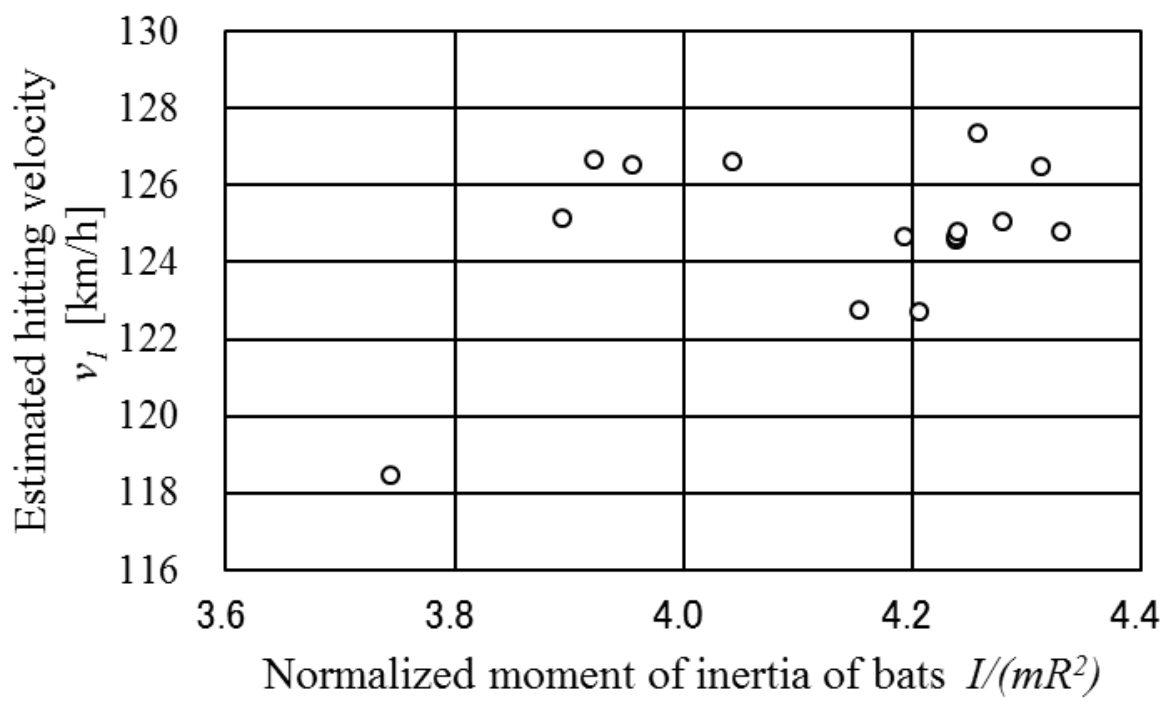

Fig.7 Estimated hitting velocity for each bat at pitting velocity $100[\mathrm{~km} / \mathrm{h}]$

\section{4. 結 言}

本研究では, 野球バットの打撃性能を定量的に把握するために, 前報で作成した打撃性能評価システムよる打 撃試験の結果を使って，投球速度の影響を受けない新しい評価方法を提案した．評価実験により得られる投球速 度と打球速度の関係を表す 2 つ定数パラメータ $\mathrm{a}$ および $\mathrm{b}$ を使って, バットの打撃性能を表現できるようにな っている．打撃性能評価值として，野球バットの反発効率（打撃による損失エネルギーの少なさ）を表す打撃効 率係数 $h_{e}$ ，打撃による打球の速さを表寸打球速度係数 $h_{v}$ を提案した. これらの評価係数は，a，b の他に投球速 度を与えれば求めることができ, 無次元化したバットの慣性モーメント $I /\left(m R^{2}\right)$ で整理すると, 各バットの打撃性 能を比較しやすいことを示した．また，慣性モーメントを変えられるマスコットバットを素振りすることで評価 し，打者のスイング能力を定数パラメータ Aおよび B で表現する方法を提案した. 以上の結果を総合して，投球 速度を仮定すれば，定数パラメータ $\mathrm{a} ， \mathrm{~b} ， \mathrm{~A} ， \mathrm{~B}$ を使って，選手が打撃時の打球速度を簡便に推定できることを 示した. さらに，バットの代わりに回転剛板を使い打撃性能評価することで，ボールの反発係数評価を行う方法 についても提案した.

今後，本研究で提案する方法を採用すれば，選手は個人能力に適したバットを選択しやすくなるものと期待し ている.そのためには, 製造会社がバットの打撃性能を表す定数パラメータ $a$ および $\mathrm{b}$ を消費者に提供すること, 販売店が選手のスイング能力を表す定数パラメータ AおよびBを測定できる環境を提供することなどが久かせな いと考えられる。

\section{文献}

Adair, R., ベースボールの物理学, 紀伊国屋書店 (1996). 
ASTM, Standard test method for measuring baseball bat performance factor, F1881 (1998), pp.1-4.

ASTM, Standard test method for measuring the coefficient of restitution (COR) of baseballs and softballs, F1887 (2002a), pp.1-3.

ASTM, Standard test method for measuring high-speed bat performance, F2219 (2002b), pp.1-7.

Cross, R., Impact of a ball with a bat or racket, American Association Journal of Physics Teachers, Vol.67, No.8 (1999), pp.692-702.

Drane, P. J., Sherwood, J. A. and Shaw, R. H., An experimental investigation of baseball bat durability, Engineering of Sports 6,

Vol.1 (2006), pp.5-10.

秦秀敏，宇津野秀夫，松久宽，ボールの反撥を考慮した金属バットの振動モード解析，日本機械学会ジョイント・シン ポジウム講演論文集，No. 04-26 (2004), pp. 89-94.

伊藤幸司，佐藤文宣，金子靖仙，島名孝次，バットの慣性特性がバットスイングに及ぼす影響，日本機械学会ジョイ ント・シンポジウム講演論文集，No. 01-22 (2001), pp.49-53.

Jaramillo, P., Manarky, K., Adrezin, R. S., Celmer, R. D., Reinard, J. T. and Shetty, D., "Sweet spot" or "Sweet zone”? Modal analysis of a wooden baseball bat for design optimization, Proceedings of IMECE’03 2003 ASME International Mechanical Engineering Congress Washington, D. C. (2003), IMECE2003-41924, pp.1-7.

香川博之, 米山猛, 那須英彰, 五十嵐重人, 北川雄二郎, 高橋昌也, 佐藤一孝, 野球バットの打撃性能評価システム の製作とバット支持方法の選択，日本機械学会論文集C編，Vol. 77，No. 783 (2011)，pp.4218-4227.

神田芳文, 鳴尾丈司, 御園和則, 軟式野球ボールとバットの衝突シミュレーション, 日本機械学会ジョイント・シンポ ジウム講演論文集，No. 04-26 (2004), pp. 95-99.

城所収二, 近田彰治, 矢内利政，野球のバッティングにおける左右への打ち分けを可能にするバット角度，日本機械 学会ジョイント・シンポジウム講演論文集, No.13-34 (2013), 119,pp.1-7.

北出侑也, 酒井忍, 木川祐太, 安井浩二, 森脇俊将, 田口航, 軟式野球用複合バットに関寸る研究, 日本機械学会ジ ヨイント・シンポジウム講演論文集，No.14-40 (2014), A8.

小林裕，尾身郁哉，時枝健一，藤原誠司，新井和吉，硬式野球用金属バットの BBCORに及ぼす衝突速度の影響，日本 機械学会ジョイント・シンポジウム講演論文集, No. 14-40 (2014), A-9.

小池関也，川村卓，阿江通良，野球打撃動作における四肢関節のトルク・パワー，日本機械学会ジョイント・シンポジ ウム講演論文集, No.06-35 (2006), pp.110-115.

前田正登，野村治夫，柳田康義，野球バットの特性がバットスイングに及ぼす影響，日本機械学会ジョイント・シンポ ジウム講演論文集，No.00-38 (2000), pp.21-25.

鳴尾丈司, 宮沢一敏, 佐藤文宣, FRP バットの打撃時のしびれに関する研究, 日本機械学会シンポジウム講演論文集, No. 920-55 (1992), pp. 187-191.

那須英彰，香川博之，高橋昌也，米山猛，五十嵐重人，佐藤一孝，金属製野球バット用反発係数評価システムの開発， 日本機械学会ジョイント・シンポジウム講演論文集，No. 05-16 (2005), pp.9-13.

Nathan, A. M., Dynamics of the baseball-bat collision, American Association Journal of Physics Teachers, Vol.68, No.11 (2000), pp.979-990.

Nathan, A. M., Russell, D. A., Smith, L. V., The physics of the trampoline effect in baseball and softball bats, Proceeding of the 5th International Conference on Sports Engineering, Vol. 2 (2004), pp. 38-44.

Nicholls, R. L., Miller, K. and Elliott, B. C., Modeling deformation behavior of the baseball, Journal of Applied Biomechanics, Vol.21 (2005), pp.18-30.

西川範浩, 西脇剛史, 森貞樹, バットの力学的特性が反発特性に及ぼす影響, 日本機械学会ジョイント・シンポジウム 講演論文集, No. 940-59 (1994), pp.21-25.

仁村亮介，香川博之，米山猛，高橋昌也，金属製野球バッ卜打撃性能試験における支持方法の影響に関する数值解析， 日本機械学会 2011 年度年次大会 DVD-ROM 論文集，No.11-1 (2011)，J231014，pp.1-3.

尾田十八, 酒井忍, 米村茂, 河田憲吾, 野球ボールの衝撃力測定とシミュレーション解析, 日本機械学会ジョイント・シ ンポジウム講演論文集，No. 04-26 (2004),pp. 100-103.

Russell, D., Bending modes, damping, and the sensation of sting in baseball bats, Engineering of Sports 6, Vol.1 (2006), pp.11-16. 背戸一登，山下繁生，人に優しいバットの開発，日本機械学会シンポジウム講演論文集，No. 920-55 (1992), pp. 182-195.

Smith, L. V., Evaluating baseball bat performance, Sports Engineering, Vol.4 (2001), pp.205-214.

Smith, L. and Ison, A., Rigid wall effect on softball coefficient of restitution measurements, Engineering of Sports 6, Vol.1 (2006), pp.29-34.

高木隆司，スポーツの力学，講談社 (1983).

田中皓一, 増田泰亮, 児玉斎, 硬式野球バットと球の高速衝撃, 日本機械学会論文集A 編, Vol. 58, No. 556 (1992), pp. 2365-2369. 
渡邊敬人，岩原光男，野球用金属バットの振動と打撃性能に関する研究，日本機械学会論文集 C編，Vol. 79，No. 799 (2013), pp.479-494.

\section{References}

Adair, R., Physics of baseball, Kinokuniya-Shoten (1996), (in Japanese).

ASTM, Standard test method for measuring baseball bat performance factor, F1881 (1998), pp.1-4.

ASTM, Standard test method for measuring the coefficient of restitution (COR) of baseballs and softballs, F1887 (2002a), pp.1-3.

ASTM, Standard test method for measuring high-speed bat performance, F2219 (2002b), pp.1-7.

Cross, R., Impact of a ball with a bat or racket, American Association Journal of Physics Teachers, Vol.67, No.8 (1999), pp.692-702.

Drane, P. J., Sherwood, J. A. and Shaw, R. H., An experimental investigation of baseball bat durability, Engineering of Sports 6 , Vol.1 (2006), pp.5-10.

Hata, H., Utsuno, H.and Matsuhisa, H., Modal analysis of a metal baseball bat considering the restitution of ball, Proceedings of JSME Symposium on Sports Engineering, No.04-26 (2004), pp.89-94 (in Japanese).

Ito, K., Sato, F., Kaneko, Y. and Shimana, T., Effect of inertia properties of bat on swinging, Proceedings of JSME Symposium on Sports Engineering, No. 01-22 (2001), pp.49-53 (in Japanese).

Jaramillo, P., Manarky, K., Adrezin, R. S., Celmer, R. D., Reinard, J. T. and Shetty, D., "Sweet spot” or “Sweet zone”? Modal analysis of a wooden baseball bat for design optimization, Proceedings of IMECE'03 2003 ASME International Mechanical Engineering Congress Washington, D. C. (2003), IMECE2003-41924, pp.1-7.

Kagawa, H., Yoneyama, T., Nasu, H., Igarashi, S., Kitagawa, Y., Takahashi, M. and Sato, K., Development of the evaluating system on hitting performance and choice of clamping methods for baseball bats, Transactions of the Japan Society of Mechanical Engineers, Series C, Vol. 77, No. 783 (2011), pp.4218-4227 (in Japanese).

Kanda, Y., Naruo, T. and Misono, K., Simulation of impact between rubber-ball and bat for baseball, Proceedings of JSME Symposium on Sports Engineering, No. 04-26 (2004), pp.95-99 (in Japanese).

Kidokoro, S., Konda, S. and Yanai, t., Three-dimensional orientation of baseball bat at ball impact: Probability of directing the batted ball toward the same and opposite fields, Proceedings of JSME Symposium on Sports Engineering, No.13-34 (2013), 119, pp.1-7(in Japanese).

Kitade, Y., Sakai, S.,Kikawa, Y., Yasui, K., Moriwaki, T. and Taguchi, W., A study on composite bat for rubber-ball baseball, Proceedings of JSME Symposium on Sports Engineering, No.14-40 (2014), A8 (in Japanese).

Kobayashi, Y., Omi, F., Tokieda, K., Fujihara, S. and Arai, K., Effect of impact velocity on bat-ball coefficient of restitution of metal baseball bat, Proceedings of JSME Symposium on Sports Engineering, No. 14-40 (2014), A-9 (in Japanese).

Koike, S., Kawamura, T. and Ae, M., Joint torque powers of the upper and lower limbs during baseball batting motion, Proceedings of JSME Symposium on Sports Engineering, No.06-35 (2006), pp.110-115 (in Japanese).

Maeda, M., Nomura, H. and Yanagida, Y., The effect of the characteristics of baseball bat on swing, Proceedings of JSME Symposium on Sports Engineering, No.00-38 (2000), pp.21-25 (in Japanese).

Naruo, T., Miyazawa, K. and Sato, F., A study of paralysis of FRP bat on hitting, Proceedings of JSME Symposium on Sports Engineering, No. 920-55 (1992), pp. 187-191 (in Japanese).

Nasu, H., Kagawa, H., Takahashi, M., Yoneyama, T., Igarashi, S. and Sato, K., Development of an evaluation system for coefficient of restitution on metal baseball bat, Proceedings of JSME Symposium on Sports Engineering, No. 05-16 (2005), pp.9-13 (in Japanese).

Nathan, A. M., Dynamics of the baseball-bat collision, American Association Journal of Physics Teachers, Vol.68, No.11 (2000), pp.979-990.

Nathan, A. M., Russell, D. A., Smith, L. V., The physics of the trampoline effect in baseball and softball bats, Proceeding of the 5th International Conference on Sports Engineering, Vol. 2 (2004), pp. 38-44.

Nicholls, R. L., Miller, K. and Elliott, B. C., Modeling deformation behavior of the baseball, Journal of Applied Biomechanics, Vol.21 (2005), pp.18-30.

Nishikawa, N., Nishiwaki, T. and Mori, S., Influence of the mechanical properties on the coefficient of restitution for baseball bats, Proceedings of JSME Symposium on Sports Engineering, No. 940-59 (1994), pp.21-25 (in Japanese).

Nimura, R., Kagawa, H., Yoneyama, T. and Takahashi, M., Numerical analysis on influence of support methods for metal baseball bat performance test, Proceedings of JSME annual meeting DVD-ROM, No.11-1 (2011), J231014, pp.1-3 (in Japanese).

Oda, J., Sakai, S. and Yonemura, S., Impact force measurement and simulation analysis of the baseball, Proceedings of JSME 
Symposium on Sports Engineering, No. 04-26 (2004), pp. 100-103 (in Japanese).

Russell, D., Bending Modes, Damping, and the sensation of sting in baseball bats, Engineering of Sports 6, Vol.1 (2006), pp.11-16.

Seto, K. and Yamashita, S., Development of the bat which is kind to a person, Proceedings of JSME Symposium on Sports

Engineering, No. 920-55 (1992), pp. 182-195 (in Japanese).

Smith, L. V., Evaluating baseball bat performance, Sports Engineering, Vol.4 (2001), pp.205-214.

Smith, L. and Ison, A., Rigid Wall effect on softball coefficient of restitution measurements, Engineering of Sports 6, Vol.1, (2006), pp.29-34.

Takagi, T., Mechanics of sports, Koudansha (1983) (in Japanese).

Tanaka, K., Masuda, T. and Kodama, A., High-speed impact of baseball bats and balls (1st Report, Impact of Aluminum Alloy Bats and Balls), Transactions of the Japan Society of Mechanical Engineers, Series A, Vol. 58, No. 556 (1992), pp. $2365-2369$ (in Japanese).

Watanabe, T. and Iwahara, M., Vibration and performance of metal bat for baseball, Transactions of the Japan Society of Mechanical Engineers, Series C, Vol. 79, No. 799 (2013), pp.479-494 (in Japanese). 